University of Nebraska - Lincoln

DigitalCommons@University of Nebraska - Lincoln

\title{
IN VITRO TESTOSTERONE SECRETION BY TESTICULAR TISSUE FROM YOUNG BULLS AND THE EFFECTS OF CHRONIC AND ACUTE EXPOSURE TO ESTRADIOL- $17 \beta$
}

\author{
M. J. D'Occhio \\ University of Nebraska-Lincoln \\ B. D. Schanbacher \\ USDA-ARS \\ J. E. Kinder \\ University of Nebraska-Lincoln, kinder.15@osu.edu
}

Follow this and additional works at: https://digitalcommons.unl.edu/usdaarsfacpub

Part of the Agricultural Science Commons

D'Occhio, M. J.; Schanbacher, B. D.; and Kinder, J. E., "IN VITRO TESTOSTERONE SECRETION BY TESTICULAR TISSUE FROM YOUNG BULLS AND THE EFFECTS OF CHRONIC AND ACUTE EXPOSURE TO ESTRADIOL- 17ß" (1984). Publications from USDA-ARS / UNL Faculty. 768.

https://digitalcommons.unl.edu/usdaarsfacpub/768

This Article is brought to you for free and open access by the U.S. Department of Agriculture: Agricultural Research Service, Lincoln, Nebraska at DigitalCommons@University of Nebraska - Lincoln. It has been accepted for inclusion in Publications from USDA-ARS / UNL Faculty by an authorized administrator of DigitalCommons@University of Nebraska - Lincoln. 


\title{
IN VITRO TESTOSTERONE SECRETION BY TESTICULAR TISSUE FROM YOUNG BULLS AND THE EFFECTS OF CHRONIC AND ACUTE EXPOSURE TO ESTRADIOL-17 $\beta^{1}$
}

\author{
M. J. D'Occhio 2,3 , B. D. Schanbacher ${ }^{4,5}$ and J. E. Kinder ${ }^{2}$ \\ University of Nebraska, Lincoln 68583 \\ and \\ US Department of Agriculture, Clay Center, NE 68933
}

\begin{abstract}
Summary
The possibility that estradiol-17 $\beta$ may directly influence testicular steroidogenesis in bulls was investigated in vitro. Testicular tissues were incubated for $4 \mathrm{~h}$ and regression coefficients $\left(\mathrm{b}, \mathrm{ng} \cdot \mathrm{ml}^{-1} \cdot \mathrm{h}^{-1}\right)$ based on the increase in testosterone in the medium were used to describe testosterone secretion rates. In the first experiment, testicular tissues from control bulls and bulls chronically implanted with estradiol were incubated in the absence (basal conditions) or presence of $10 \mathrm{mIU} / \mathrm{ml}$ human chorionic gonadotropin (hCG). Under basal conditions, testosterone secretion rates were similar for tissues from control $(b=24.1 \pm 6.0)$ and implanted $(b=$ $34.7 \pm 6.0$ ) bulls. Testosterone secretion rates were increased approximately fourfold during incubation with hCG; tissues from implanted animals secreted testosterone at a higher rate $(\mathrm{P}<.05)$ than control tissues $(b=120.7 \pm 6.0$ vs $81.6 \pm 6.0$ ). In a second experiment, testicular tissues were obtained from control bulls and incubated both with and without hCG $(10 \mathrm{mIU} / \mathrm{ml})$ and with
\end{abstract}

\footnotetext{
${ }^{1}$ Published as Paper No. 6625, Journal Series, Nebraska Agr. Exp. Sta. We are grateful to Cindy Rainbolt for technical assistance and Michael MacNeil for advice on analysis of data. We also thank Kathy Leising for typing the manuscript.

${ }^{2}$ Dept. of Anim. Sci., Univ. of Nebraska.

${ }^{3}$ A University of Nebraska Research Fellow located at the Roman L. Hruska U.S. Meat Animal Research Center, Clay Center, NE.

' Roman L. Hruska U.S. Meat Animal Research Center, ARS, USDA.

${ }^{5}$ Reprint requests: Dr. B. D. Schanbacher, Roman L. Hruska U.S. Meat Animal Research Center, P.O. Box 166, Clay Center, NE 68933.

Received May 23, 1983.

Accepted September 30, 1983.
}

and without estradiol (concentrations ranging from $3.7 \mathrm{nM}$ to $37 \mu \mathrm{M}$ ). In this experiment, basal secretion rate $(b=12.6 \pm 3.6)$ was increased threefold during incubation with hCG ( $b=37.8 \pm 3.6)$. Estradiol failed to inhibit hCG-stimulated testosterone secretion when bovine testicular tissue was incubated with $0,3.7$ and $370 \mathrm{nM}$ estradiol. In contrast, $37 \mu \mathrm{M}$ estradiol suppressed $(\mathrm{P}<.05)$ testosterone secretion, perhaps reflecting a pharmacologic effect. The results suggest that neither chronic nor acute exposure to estradiol directly affects testosterone secretion by the bovine testis. It is proposed, therefore, that the negative effects of chronic estradiol treatment on testicular development, previously reported in young bulls, are mediated by changes in luteinizing hormone secretion rather than by direct actions on the testes.

(Key Words: Bulls, Testis, Testosterone Secretion, Estradiol-17 $\beta$, Human Chorionic Gonadotropin.)

\section{Introduction}

In recent studies with young bulls, chronic treatment with estradiol-17 $\beta$ (estradiol) retarded testicular growth normally associated with pubertal development (Schanbacher, 1981a, 1984; Schanbacher et al., 1982). Young bulls bearing estradiol implants had nearnormal mean luteinizing hormone ( $\mathrm{LH}$ ) concentrations but markedly reduced serum testosterone concentrations (Schanbacher et al., 1982; Schanbacher, 1984). These findings, together with comparable observations in rats (Steinberger et al., 1977), rhesus monkeys (Steiner et al., 1978) and men (Sawin et al., 1978), suggested that estradiol may have a direct negative inhibitory effect on the testes. Such a direct action of estradiol on 949

testicular steroidogenesis was demonstrated 
in a number of in vitro studies utilizing tissues from rats (Bartke et al., 1977; Moger, 1980) and men (Yanaihara and Troen, 1972; Rodriguez-Rigau et al., 1977). It was subsequently shown that this direct action of estradiol on the Leydig cell involves decreases in the activities of key microsomal enzymes associated with testosterone biosynthesis (Nozu et al., 1981; Onoda and Hall, 1981; Rommerts and Brinkman, 1981).

The objectives of the present study were to determine the effects of chronic and acute exposure to estradiol on in vitro testosterone secretion by testicular tissues from young bulls. In the first experiment, testicular tissue from young bulls that had been chronically implanted with estradiol was incubated in the presence or absence of human chorionic gonadotropin (hCG). In a second experiment, testicular tissue from normal bulls was incubated in the presence or absence of hCG and graded concentrations of estradiol. The release of testosterone into the incubation medium over time was used as an index of steroidogenic activity in both experiments.

\section{Materials and Methods}

Reagents. Testosterone and estradiol-17 $\beta$ were obtained from Sigma Chemical Co., St. Louis, Missouri. The $\left[1,2,6,7,16,17-{ }^{3} \mathrm{H}\right]$ testosterone was purchased from New England Nuclear, Boston, Massachusetts. Other reagents were obtained as follows: tissue culture (TC) medium 199 with Earle's salts and L-glutamine from Gibco Laboratories, Grand Island, New York; N-2-hydroxyethyl piperazine-N-2ethansulphonic acid (Hepes) from ICN Pharmaceuticals, Inc., Cleveland, Ohio; human chorionic gonadotropin (hCG) from Research Plus Steroid Laboratories, Inc., Denville, New Jersey.

In Vitro Incubations. The preparation of testicular tissues and conditions during in vitro incubation were based on procedures described by McCarthy et al. (1979). Samples of testicular parenchyma $(500 \mathrm{mg})$ were taken at random and placed into $25 \mathrm{ml}$-Erlenmeyer flasks containing $5 \mathrm{ml}$ of TC medium 199 (25 mM Hepes; $26.2 \mathrm{mM}$ sodium bicarbonate; $\mathrm{pH} 7.2$ ). The tissue was cut into small cubes $\left(\sim 1 \mathrm{~mm}^{3}\right)$ and once the required number of flasks had been prepared, they were assigned randomly to different treatments that were run in triplicate. After a 30 min preincubation (McCarthy et al., 1979), the entire contents of the flasks were decanted into $13 \times 85 \mathrm{~mm}$ glass tubes that were capped and centrifuged at $800 \times \mathrm{g}$ for $5 \mathrm{~min}$. An aliquot of the supernatant was retained for testosterone determination and the tissue pellet resuspended in $5 \mathrm{ml}$ of fresh TC medium 199 containing the various treatments, and returned to $25-\mathrm{ml}$ Erlenmeyer flasks. The flasks were incubated for an additional $4 \mathrm{~h}$, during which time aliquots $(100 \mu \mathrm{l})$ of the incubation medium were taken at $1,2,3$ and $4 \mathrm{~h}$. Media were stored at $-20 \mathrm{C}$ until assayed for testosterone.

Exp. 1. Testicular tissues were obtained from six Hereford bulls (mean body weight $315.8 \pm 5.6 \mathrm{~kg}$ ) that were used in a companion study to investigate the effects of chronic estradiol treatment on $\mathrm{LH}$ and testosterone secretion and testicular development in these animals (Schanbacher et al., 1982). Three of the bulls served as controls and did not receive any hormone treatment. The other three bulls were implanted at 26 wk of age with a Silastic capsule $(3.35 \mathrm{~mm}$ id $\times 4.65$ $\mathrm{mm}$ od $\times 27 \mathrm{~cm}$ ) filled with crystalline estradiol. All animals were castrated at 42 wk of age. Testes were placed on ice at the time of castration and processed within $1 \mathrm{~h}$ of collection. After preincubation, tissues in triplicate were placed in fresh TC medium 199 containing either 0 or $10 \mathrm{mIU} / \mathrm{ml} \mathrm{hCG}$. A concentration of $10 \mathrm{mIU} / \mathrm{ml}$ hCG was used because in the present system this quantity of hCG produces near maximal stimulation of testosterone secretion by bovine tissues. Tissues were incubated for $4 \mathrm{~h}$, during which time samples of the medium were taken as described above.

Exp. 2. Testes were obtained from four 10-mo-old untreated Hereford crossbred bulls (body weight $283.3 \pm 11.9 \mathrm{~kg}$ ) and prepared for incubation within $1 \mathrm{~h}$ of collection. After preincubation, testicular tissues in triplicate were incubated for a further $4 \mathrm{~h}$ under the following conditions: basal (no hCG); basal + $.001(3.7 \mathrm{nM}), .1(370 \mathrm{nM})$ or $10 \mu \mathrm{g} / \mathrm{ml}(37$ $\mu \mathrm{M})$ estradiol; stimulation with $10 \mathrm{mIU} / \mathrm{ml}$ hCG; $10 \mathrm{mIU} / \mathrm{ml} \mathrm{hCG}+.001, .1$ or $10 \mu \mathrm{g} / \mathrm{ml}$ estradiol. Estradiol was added to the medium in propylene glycol such that the concentration of the solvent was constant at $50 \mu \mathrm{l} / \mathrm{ml}$. At this concentration, propylene glycol has no effect on testosterone secretion (M. J. D'Occhio and B. D. Schanbacher, unpublished data). Samples of the medium were taken at hourly intervals during the $4-\mathrm{h}$ incubation. 


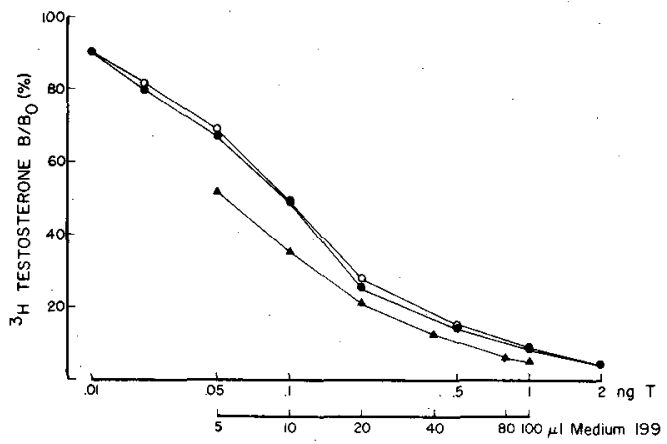

Figure 1. Standard curves for the testosterone direct radioimmunoassay using standards prepared in assay buffer ( $\bullet$ ) and TC medium $199(\circ)$. Also shown is the displacement of $\left[{ }^{3} \mathrm{H}\right]$-testosterone obtained by assaying increasing volumes of medium that had been incubated with testicular tissue for $2 \mathrm{~h}(4)$. Each point is the mean of three replicates. In all cases, the SE was less than $1.5 \%$.

Testosterone Radioimmunoassay. After thawing, samples of culture medium were centrifuged at $800 \times \mathrm{g}$ for $10 \mathrm{~min}$ before two aliquots $(10 \mu \mathrm{l})$ were taken for testosterone assay. The use of an antiserum that shows high affinity and specificity for testosterone allowed the direct assay of medium without prior extraction (Schanbacher and D'Occhio, 1982). After overnight incubation at $4 \mathrm{C}$, free and antibody-bound steroid was separated by the addition of dextran-coated charcoal. Testosterone standards prepared in assay buffer and in TC medium 199 gave identical inhibition curves. These curves were paralleled by a displacement curve obtained by assaying increasing volumes of TC medium 199 that had been incubated with testicular tissue for $2 \mathrm{~h}$ (figure 1 ). These results indicated that there were no constituents in the culture medium that interfered with the direct assay. The sensitivity of the assay was $.1 \mathrm{ng} / \mathrm{ml}$ and the intra- and interassay coefficients of variation were 5.4 and $7.2 \%$, respectively.

Statistical Analyses. A regression coefficient was calculated for each treatment based on the increase in testosterone in the medium over the 4-h incubation. Effects of treatment on testosterone production were tested by analyses of variance (ANOVA) on the regression coefficients. Differences between treatments were determined by linear contrasts using the t-test (Sokal and Rohlf, 1969).

\section{Results}

Exp. 1. Under basal conditions, tissues from both control and estradiol-implanted bulls secreted some testosterone in a linear manner from 1 to $4 \mathrm{~h}$ of incubation (table 1). The regression coefficients describing testosterone secretion rate did not differ for the two groups. There was a tendency, however, for testosterone concentrations to be lower in flasks containing tissues from implanted animals. These differences were not significant due to relatively large variations within the controls. Tissues from both control and implanted animals showed an increase in testosterone secretion rate during incubation with hCG. The regression coefficients indicated that tissues from implanted animals had a higher $(\mathrm{P}<.05)$ secretion rate from 1 to $4 \mathrm{~h}$ than did control tissues.

Exp. 2. Testosterone secretion rates for testicular tissues in experiment 2 are shown in table 2. Under basal conditions, there was a linear increase in the concentration of testosterone in the medium from 1 to $4 \mathrm{~h}$ of incubation. The inclusion of estradiol in the medium at concentrations ranging from $3.7 \mathrm{nM}$ to 37 $\mu \mathrm{M}$ had no effect on this increase in testosterone.

Stimulation with hCG resulted in a threefold increase in the testosterone secretion rate as indicated by the regression coefficients. The stimulatory effect of hCG was apparent by the end of the first hour and was maintained over the 4- $h$ incubation period. Estradiol had no effect on hCG-stimulated testosterone secretion when present in the medium at concentrations of 3.7 and $370 \mathrm{nM}$. However, at a concentration of $37 \mu \mathrm{M}$, estradiol suppressed $(P<.05)$ the response to hCG and the testosterone secretion rate returned to basal. This inhibitory effect of estradiol was significant from the third hour of incubation onwards.

\section{Discussion}

Previous studies in this laboratory have demonstrated that young bulls chronically implanted with estradiol show retarded testicular development and have low serum testosterone concentrations (Schanbacher, 1981a, 1984; Schanbacher et al., 1982). The purpose of the experiments described in the present study was to determine if estradiol could influence testis function in the bovine by a direct action on the Leydig cells. The results 
TABLE 1. IN VITRO TESTOSTERONE SECRETION BY TESTICULAR TISSUES FROM CONTROL AND ESTRADIOL-IMPLANTED BULLS ${ }^{2}$

\begin{tabular}{|c|c|c|c|c|c|c|}
\hline \multirow{3}{*}{$\begin{array}{c}\mathrm{hCG} \\
\mathrm{mIU} / \mathrm{ml}\end{array}$} & \multirow[b]{3}{*}{ Treatment } & \multicolumn{4}{|c|}{ Testosterone $(\mathrm{ng} / \mathrm{ml})$} & \multirow{3}{*}{$\begin{array}{c}\text { Regression coefficient, } \\
\mathrm{ng} \cdot \mathrm{ml}^{-1} \cdot \mathrm{h}^{-1}\end{array}$} \\
\hline & & \multicolumn{4}{|c|}{ Time, h } & \\
\hline & & 1 & 2 & 3 & 4 & \\
\hline $\mathbf{0}$ & $\begin{array}{l}\text { Control } \\
\text { Implanted }\end{array}$ & $\begin{array}{r}134.5 \\
55.8\end{array}$ & $\begin{array}{r}149.6 \\
96.9\end{array}$ & $\begin{array}{l}175.1 \\
131.6\end{array}$ & $\begin{array}{l}206.2 \\
159.8\end{array}$ & $\begin{array}{l}24.1 \pm 6.0 \\
34.7 \pm 6.0\end{array}$ \\
\hline 10 & $\begin{array}{l}\text { Control } \\
\text { Implanted }\end{array}$ & $\begin{array}{l}225.1 \\
124.8\end{array}$ & $\begin{array}{l}336.6 \\
246.0\end{array}$ & $\begin{array}{l}401.5 \\
381.2\end{array}$ & $\begin{array}{l}475.4 \\
489.4\end{array}$ & $\begin{aligned} 81.6 & \pm 6.0 \\
120.7 & \pm 6.0\end{aligned}$ \\
\hline
\end{tabular}

${ }^{\text {a }}$ Tissues were incubated either under basal conditions or in the presence of $10 \mathrm{mIU} / \mathrm{ml}$ hCG as described in the Materials and Methods. Results for testosterone concentration in medium are presented as least-squares means $(\mathrm{N}=3 ; \mathrm{SE}=14.6)$.

indicate that testicular tissues from estradiolsuppressed animals secrete testosterone in vitro and are responsive to hCG. This contrasts to the absence of a significant in vivo testosterone response to gonadotropic stimulation in implanted bulls (Schanbacher, 1981a). The apparent discrepancy between our in vivo and in vitro findings could be explained by correcting for testis size (testes were significantly smaller in implanted animals). Whereas testicular tissue from implanted bulls secreted normal amounts of testosterone in vitro, theoretical testosterone production by paired testes would appear to be inadequate to maintain normal blood levels (Schanbacher, 1981a). McCarthy et al. (1979) reported that testes of bulls younger than $5 \mathrm{mo}$ also show little response to LH in vivo, but secrete appreciable amounts of testosterone in vitro. These re- searchers suggested that the absence of a response to gonadotropic stimulation in vivo was due to inadequate vascularization of the immature testis. The testes of estradiolimplanted animals may therefore be similar to those of young bulls in this regard.

There is increasing evidence that suggests that initiation of normal testicular development during the prepubertal period is dependent on an increase in the frequency of pulsatile LH secretion from the pituitary (Schanbacher et al., 1982). Because estradiol abolishes pulses of LH in the bovine (D'Occhio et al., 1982; Schanbacher et al., 1982), it is proposed that the retarded testicular development observed in estradiol-implanted bulls is due to inadequate gonadotropic stimulation, rather than a direct action of estradiol on the testes (Schanbacher et al., 1982; Schan-

TABLE 2. IN VITRO TESTOSTERONE SECRETION BY TESTICULAR TISSUES FROM NORMAL BULLS INCUBATED UNDER BASAL CONDITIONS, WITH $10 \mathrm{MIU} / \mathrm{ML}$ HUMAN CHORIONIC GONADOTROPIN (hCG), AND WITH hCG $+.001, .1$ or $10 \mu \mathrm{G} / \mathrm{ML}$ ESTRADIOL $\left(\mathrm{E}_{2}\right)^{\mathrm{a}}$

\begin{tabular}{|c|c|c|c|c|c|}
\hline \multirow[b]{3}{*}{ Treatment } & \multicolumn{4}{|c|}{ Testosterone $(\mathrm{ng} / \mathrm{ml})$} & \multirow{3}{*}{$\begin{array}{c}\text { Regression coefficient, } \\
\mathrm{ng} \cdot \mathrm{ml}^{-1} \cdot \mathrm{h}^{-1}\end{array}$} \\
\hline & \multicolumn{4}{|c|}{ Time, $\mathbf{b}$} & \\
\hline & 1 & 2 & 3 & 4 & \\
\hline $\begin{array}{l}\text { Basal } \\
\text { hCG }\end{array}$ & $\begin{array}{r}66.8 \\
120.1\end{array}$ & $\begin{array}{r}81.9 \\
172.6\end{array}$ & $\begin{array}{r}91.1 \\
206.3\end{array}$ & $\begin{array}{l}105.6 \\
234.9\end{array}$ & $\begin{array}{l}12.6 \pm 3.6 \\
37.8 \pm 3.6\end{array}$ \\
\hline $\begin{array}{l}h C G+E_{2} \\
(.001 \mu \mathrm{g} / \mathrm{ml} ; 3.7 \mathrm{nM})\end{array}$ & 122.4 & 164.3 & 200.6 & 233.1 & $36.9 \pm 3.6$ \\
\hline $\begin{array}{l}\mathrm{hCG}+\mathrm{E}_{2} \\
(.1 \mu \mathrm{g} / \mathrm{ml} ; 370 \mathrm{nM})\end{array}$ & 118.6 & 149.0 & 184.0 & 220.1 & $34.0 \pm 3.6$ \\
\hline $\begin{array}{l}\mathrm{hCG}+\mathrm{E}_{2} \\
(10 \mu \mathrm{g} / \mathrm{ml} ; 37 \mu \mathrm{M})\end{array}$ & 119.8 & 126.3 & 136.1 & 148.1 & $9.5 \pm 3.6$ \\
\hline
\end{tabular}

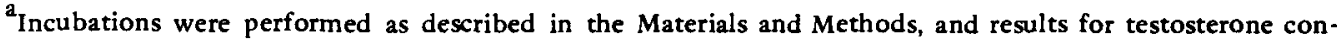
centration in medium are presented as least-squares means $(N=4 ; S E=19.4)$.
} 
bacher, 1984). Our observation that testes of estradiol-treated bulls secrete more testosterone than testes of control bulls is interesting and thus warrants further investigation.

A possible modifying influence of estradiol on Leydig cell function in the bull was originally suggested by Amann and Ganjam (1976). These researchers noted that the bovine testis not only secretes estradiol, but that there is also a countercurrent exchange of estradiol in the pampiniform plexus, such that the concentration of this estrogen in testicular arterial blood is higher than that in the general circulation. In the present study, estradiol suppressed the response of normal testicular tissues to hCG only when present in the incubation medium at a concentration of $37 \mu \mathrm{M}$. Based on this finding, estradiol would need to be concentrated approximately 500,000 -fold in the testis in order to have a negative action on the Leydig cells (Amann and Ganjam, 1976; Schanbacher and Echternkamp, 1978). It is unlikely that such a concentrating mechanism exists in the bovine testis, suggesting that $37 \mu \mathrm{M}$ estradiol may have a pharmacologic effect on the tissues. Moger (1980) suggested that the unstable nature of testicular estrogen receptors might be one reason why high concentrations of estradiol are required to demonstrate direct actions on Leydig cell steroidogenesis in vitro.

Testosterone secretion rates were increased three- to fourfold in the presence of $10 \mathrm{mIU} / \mathrm{ml}$ hCG. Comparable in vitro responses to gonadotropic stimulation have been reported previously for bovine testicular tissue (McCarthy et al., 1979; Schanbacher, 1981b). In the present study, the response to hCG was apparent at the end of the first hour and was maintained in a linear manner over the 4-h incubation. Testicular tissues also secreted testosterone under basal conditions, which was in accord with previous findings in this species (McCarthy et al., 1979; Schanbacher, 1981b). The differences in basal secretion rates and responses to hCG between the two experiments were most likely due to differences in genetic background and age of the animals.

In summary, the results of the present study suggest that the negative effects of estradiol on testis development in young bulls are mediated by changes in the pattern of $\mathrm{LH}$ secretion rather than by a direct action of estradiol on testicular steroidogenesis.

\section{Literature Cited}

Amann, R. P. and V. K. Ganjam. 1976. Steroid production by the bovine testis and steroid transfer across the pampiniform plexus. Biol. Reprod. 15:695.

Bartke, A., K. I, H. Williams and S. Dalterio. 1977. Effects of estrogen on testicular testosterone production in vitro. Biol. Reprod. 17:645.

D'Occhio, M. J., J. E. Kinder and B. D. Schanbacher. 1982. Patterns of $\mathrm{LH}$ secretion in castrated bulls (steers) during intravenous infusion of androgenic and estrogenic steroids: Pituitary response to exogenous luteinizing hormone releasing hormone. Biol. Reprod. 26:249.

McCarthy, M. S., E. M. Convey and H. D. Hafs. 1979. Serum hormonal changes and testicular response to $\mathrm{LH}$ during puberty in bulls. Biol. Reprod. 20:1221.

Moger, W. H. 1980. In vitro inhibitory effect of estradiol on testosterone production. J. Steroid Biochem. 13:61.

Nozu, K., M. L. Dufau and K. J. Catt. 1981. Estradiol receptor-mediated regulation of steroidogenesis in gonadotropin-desensitized Leydig cells. J. Biol. Chem. 256:1915.

Onoda, M. and P. F. Hall. 1981. Inhibition of testicular microsomal cytochromone P-450 (17 $\alpha-$ hydroxylase/C-17,20-lyase) by estrogens. Endocrinology 109:763.

Rodriguez-Rigau, L. J., R. K. Tcholakian, K. D. Smith and E. Steinberger. 1977. In vitro steroid metabolic studies in human testes. 1. Effects of estrogen on progesterone metabolism. Steroids 29:771.

Rommerts, F.F.G. and A. O. Brinkman. 1981. Modulation of steroidogenic activities in testis Leydig cells. Mol. Cell. Endocrinol. 21:15.

Sawin, C. T., R. J. Ryan, C. Longcope and L. E. Fisher. 1978. Effect of chronic administration of estrogen, androgen, or both on serum levels of gonadotropins in adult men. J. Clin. Endocrinol. Metab. 46:911.

Schanbacher, B. D. 1981a. Importance of the episodic nature of luteinizing hormone secretion for normal development of the bovine testis during puberty: Interference with oestradiol17ß. J. Endocrinol. 88:393.

Schanbacher, B. D. 1981b. Cryptorchidism and the pituitary-testicular axis in bulls. J. Reprod. Fertil. Suppl. 30:67.

Schanbacher, B, D. 1984. Pituitary-testicular responses of estradiol-17 $\beta$-implanted bull calves to continuous versus pulsatile infusion of luteinizing hormone releasing hormone. J. Anim. Sci. 58:943.

Schanbacher, B. D. and M. J. D'Occhio. 1982. Validation of a direct radioimmunoassay for testosterone in unextracted serum from five species: Application to the study of the hypothalamicpituitary-gonadal axis in males. J. Androl. $3: 45$.

Schanbacher, B. D., M. J. D'Occhio and J. E. Kinder. 1982. Initiation of spermatogenesis and testicular growth in oestradiol-17 $\beta$-implanted bull calves with pulsatile infusion of luteinizing hormone releasing hormone. J. Endocrinol. 93:183. 
Schanbacher, B. D. and S. E. Echternkamp. 1978. Testicular steroid secretion in response to GnRHmediated LH and FSH release in bulls. J. Anim. Sci. 47:514.

Sokal, R. R. and F. J. Rohlf. 1969. Biometry. W. H. Freeman, San Francisco. pp 458.

Steinberger, E., M. Chowdhury and R. Tcholakian. 1977. Effect of estradiol benzoate on the pituitary-gonadal axis in the intact male rat. Andrologia 9:307.
Steiner, R. A., H. S. Schiller, J. Barber and C. C. Gale. 1978. Luteinizing hormone regulation in the monkey (Macaca nemestrina): Failure of testosterone and dihydrotestosterone to block the estrogen-induced gonadotropin surge. Biol. Reprod. 19:51.

Yanaihara, T. and P. Troen. 1972. Studies on human testis. III. Effect of estrogen on testosterone formation in human testis in vitro. J. Clin. Endocrinol. Metab. 34:968. 